\title{
INFORMATION SYSTEM OF CONSTRUCTION SERVICE WEB BASED ON PAPUA GAPEKSINDO ASSOCIATION
}

\author{
Mutmainna $^{1}$, Sitti Nur Alam ${ }^{2}$, M. Raindi Widiantoro ${ }^{3}$, Salahudin Robo ${ }^{4}$ \\ ${ }^{1,2,3,4}$ Program Studi Sistem Informasi, Fakultas Teknik dan Sistem Informasi, Universitas Yapis Papua
}

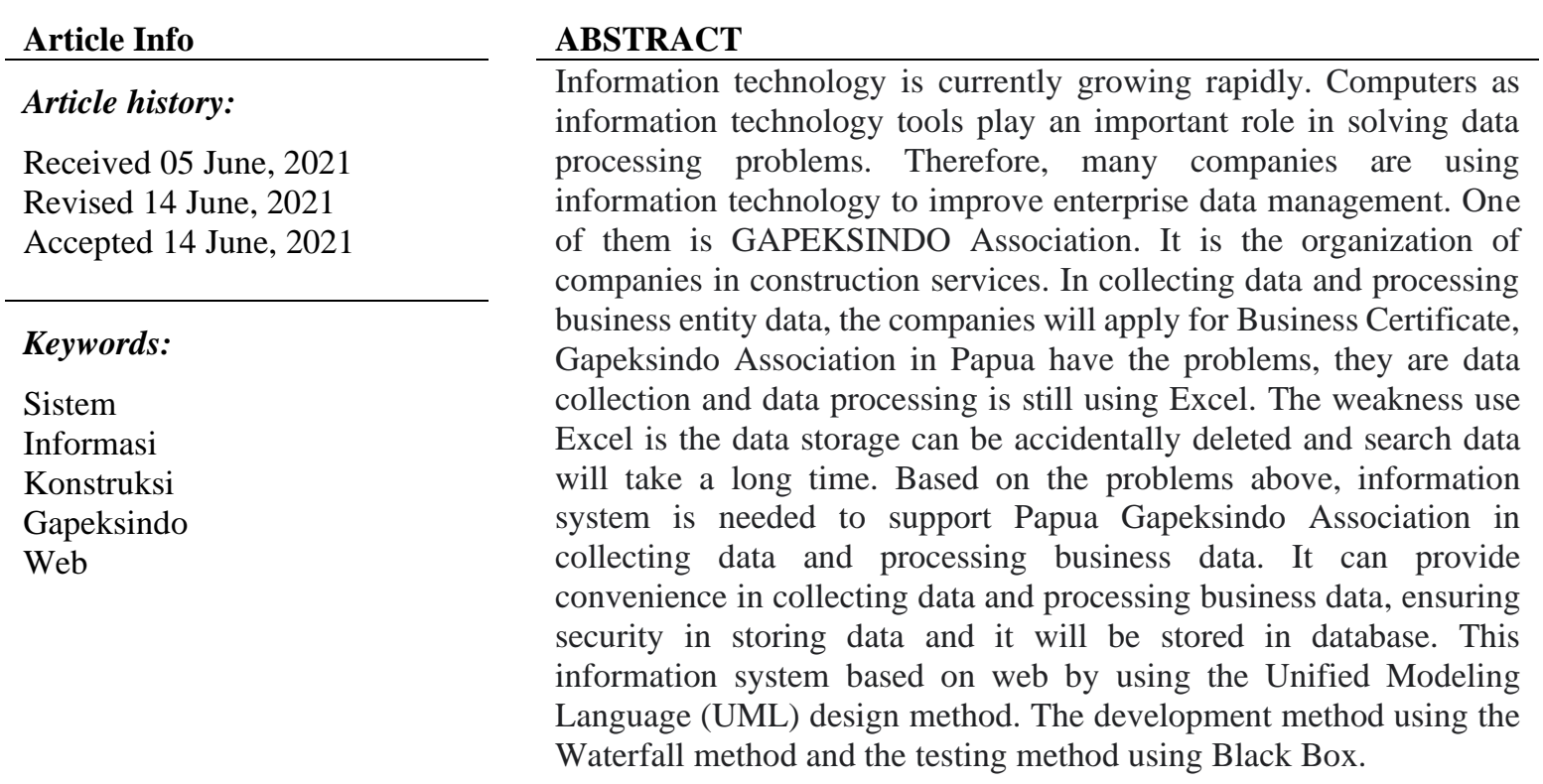

This is an open access article under the CC BY-SA license.

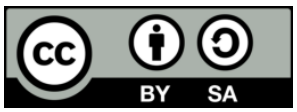

\author{
Corresponding Author: \\ Mutmainna \\ Program Studi Sistem Informasi, Fakultas Teknik dan Sistem Informasi \\ Universitas Yapis Papua \\ Papua, Indonesia \\ Email: mutiinna879@gmail.com \\ (C) The Author(s) 2021
}

\section{Introduction}

Information technology is currently growing rapidly. Computers as information technology tools play an important role in solving data processing problems. The way to improve company management is to build a good information system. Therefore, many companies are using information technology to improve enterprise data management. Almost all fields of bussiness have information technology. One of them is construction service business field.

GAPEKSINDO Association or the Indonesian National Construction Company Association is the organization of companies in construction services. In collecting data and processing business entity data, the companies 
will apply for Business Certificate, Gapeksindo Association in Papua have the problems, they are data collection and data processing is still using Excel. The weakness use Excel is the data storage can be accidentally deleted and search data will take a long time. In addition, because the data collection or data processing is conducted by several admins, the input data will be difficult to combine to make a report.

Based on the problems above, information system is needed to support Papua Gapeksindo Association in collecting data and processing business data. It can provide convenience in collecting data and processing business data, ensuring security in storing data and it will be stored in database. With the new system, it is hoped that the manual data collection or inputting data in Microsoft Excel can process and manage business entity data to be more organized.

\section{Research Method}

Information system is a structured system consist of basic computer components, they are: software, hardware, databases, and users [1] which functions to collect, to store, and to manage data to provide output information to users. Information system is interrelated and integrated system be a single unit to provide a common goal $[2]$.

\subsection{Research methodology}

\subsubsection{Data Collection Method}

The data collection methods used interviews, observations and literature studies.

\section{Interview}

Interview is a dialogue with a specific purpose between two parties to obtain accurate data from the right sources [3]. Interviews were conducted with the Head of the VVA Team (Verification and Validation) of Papua Gapeksindo Association, it is part of checking whether the file has been verified and valid or not. The second interview was conducted with the admin of Papua Gapeksindo Association as the user of the system.

\section{Observation}

Observation is a method of collecting data by directly observing the situation occured [4]. In this study, directly reviewed Gapeksindo Association office in Papua Province.

\section{Literature Study}

Literature study is a way to collect information from previous research. Several previous articles and journals related to the problems mentioned in this study are used as references and comparisons from different sources and different years of references.

\subsubsection{Analysis Method}

The system analysis method used in this study is the PIECES method. It is a way to recognize an Information System in terms of Performance, Information, Economics, Control, Efficiency and Service.

This method was chosen to describe the problems in the running system into several aspects such as aspects of performance, information, economy, control, efficiency, and service [5].

\subsubsection{Design Method}

The design method used in this study is Unified Modeling Language (UML). UML is appropriate method to solve problem in making website-based designs, it consists of four types, namely Use Case Diagrams, Class Diagrams, Sequence Diagrams and Activity Diagrams.

\subsubsection{Development Method}

The development method used in this study is Waterfall method. This method takes a systematic approach where the work of system is conducted sequentially and interrelated phases. Each phase must be completed first before proceeded to the next phase to avoid repetition and to repair an error easily [6].

\subsubsection{Testing Method}

The testing method used in this study is blackbox testing, it focuses on the functional requirements of the software to find out the system response of the input given by the user [7]. From that response of the system, it can be seen whether the system has been running well or not.

\subsection{System Design}

The system design is designed after analyzing the current system. The system design in this study consists of process design and database design. 


\subsubsection{Process Design}

The process design on this system is designed using the Unified Modeling Language (UML) which consists of Use Case Diagrams, Class Diagrams, Sequence Diagrams and Activity Diagrams.

\section{Use Case Diagrams}

Use case diagram is description of the interaction between actors and the system [8]. The use case diagram proposed in this system contains admin actors who can process business entities, leaders, workers, certificates, classifications \& qualifications. It can be seen in the following Figure:

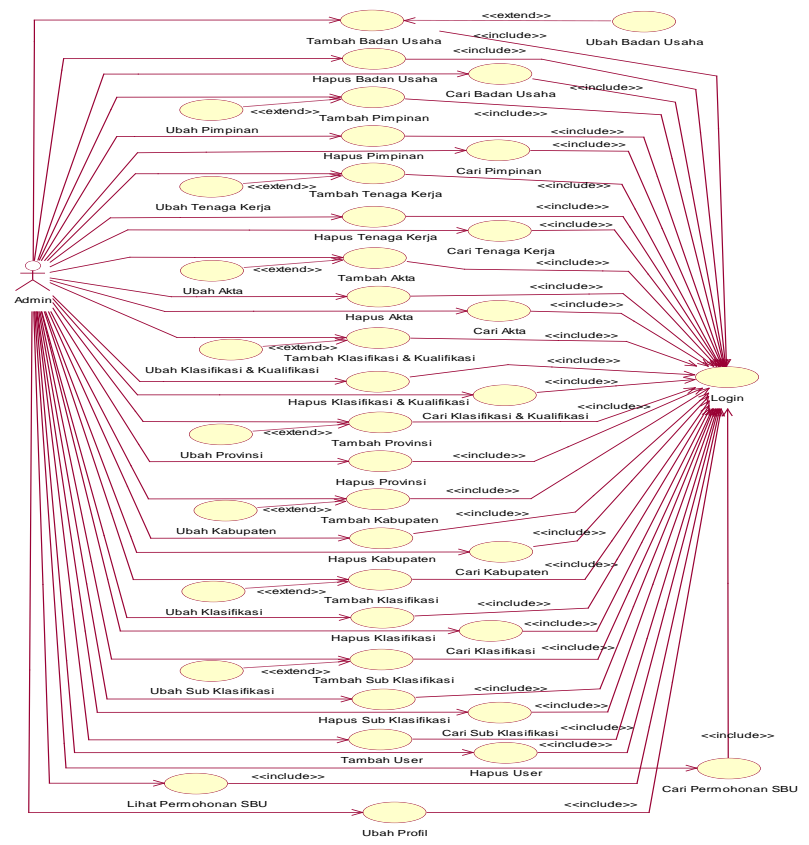

Figure 1 Use Case Diagram of Admin

\section{Class Diagrams}

Class Diagram describes the static structure of the classes in the system and describes the properties, operations and relationships between classes [9]. The proposed class diagram of this system can be seen in the following Figure:

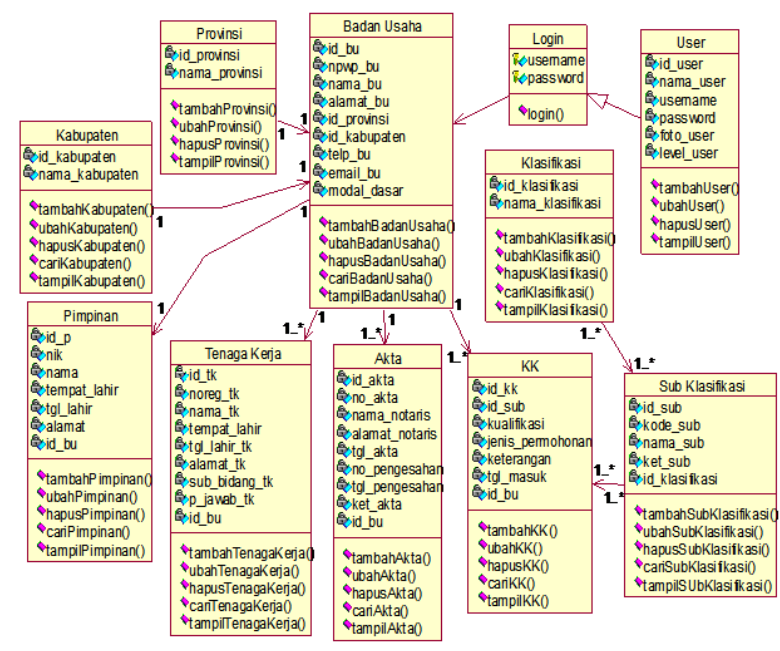

Figure 2 Class Diagram 


\section{Sequence Diagram}

Sequence Diagrams describes the interactions between objects in and around the system including users and views. The sequence diagram proposed in this system includes business entity sequence diagram and kk sequence diagram. It can be seen in the following Figure:

Admin must login first to be able to add, to change, to delete and to search for business entities.

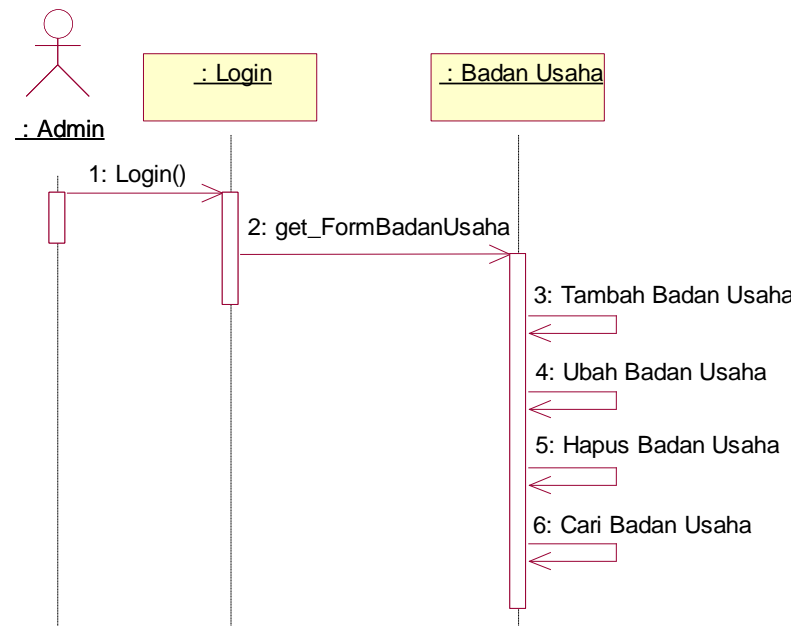

Figure 3 Sequence Diagram of Badan Usaha

Admin, VVA team leader and general chief must first login to be able to search, to view, to print SBU application and SBU application report.

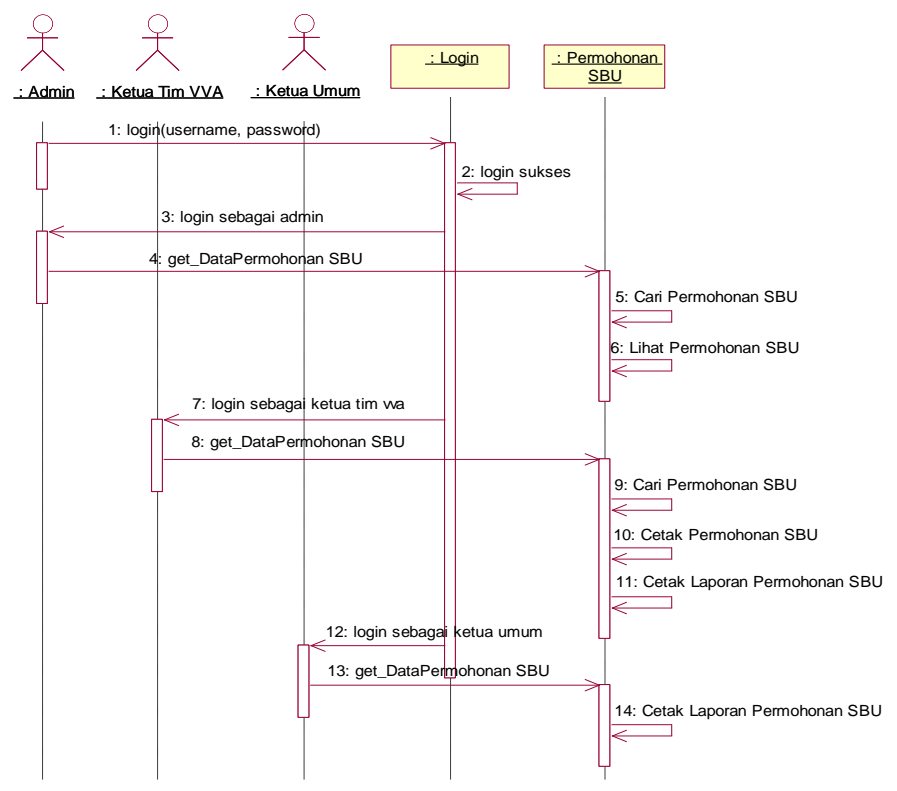

Figure 4 Sequence Diagram of Permohonan SBU

\section{Activity Diagrams}

Activity Diagrams describe the flow of various activities in the designed system and find out the needed data to be processed in the system. The activity diagram proposed in this system contains activity diagram of business entity and an activity diagram of SBU application. It can be seen in the following Figure:

In the business entity activity diagram there are several activities can be done, such as add, change, delete and search for business entities. 


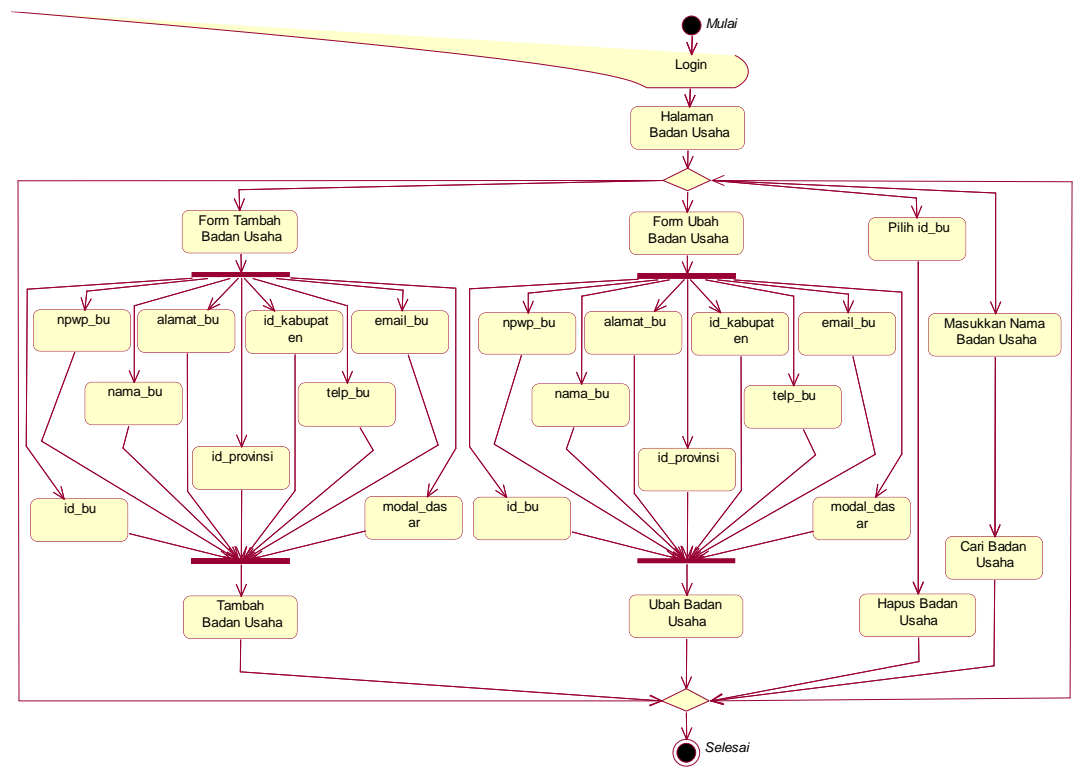

Figure 5 Activity Diagram of Badan Usaha

In the activity diagram of SBU application, there are several activities can be done, such as search, view, print SBU application and SBU application report.

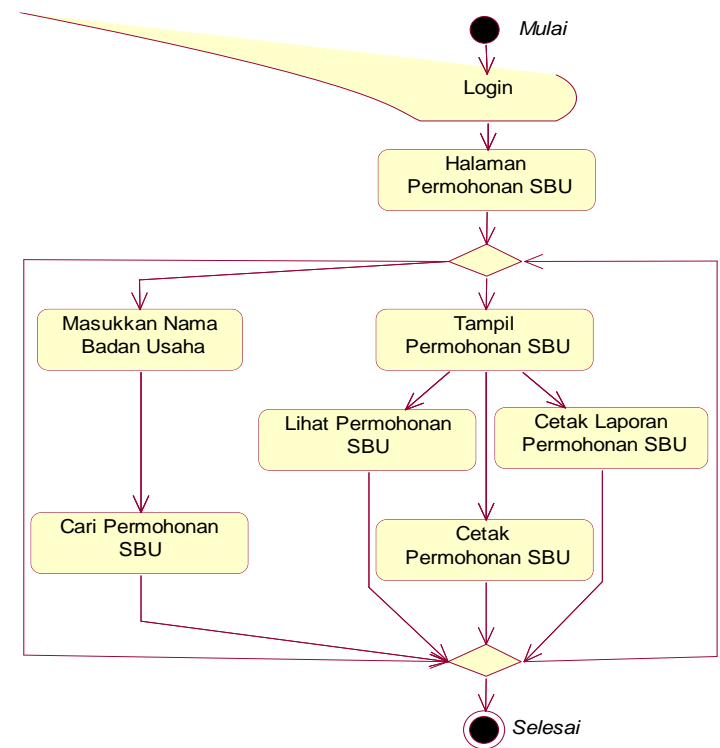

Figure 6 Activity Diagram of Permohonan SBU

\subsubsection{Database Design}

The database design on this system is designed using table relations. It describes the relationship between tables in the database. The table relations proposed in this system can be seen in the following Figure: 


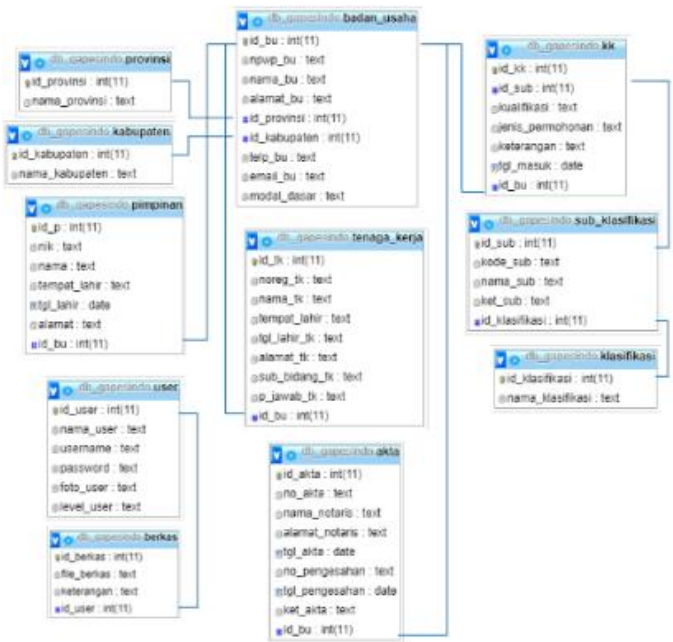

Figure 7 Table Relation

\section{Results and Discussion}

\subsection{Login Page Display}

The login page is the main display in this system. Before entering the main page, the user must login first. This page can be accessed the users by entering username and password.

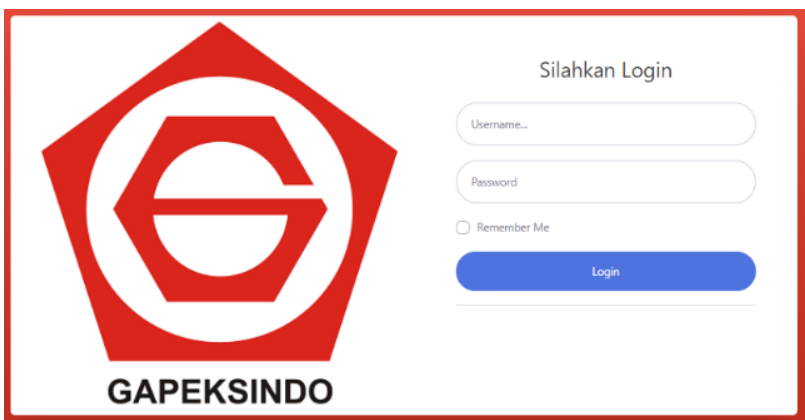

Figure 8 Login Page Display

\subsection{Main Menu Page Display}

After the admin login, the main menu page will be displayed. On the main menu page there are several menus consist of provincial \& district menus, KK master, incoming files, business entities, leaders, workers, certificates, classification \& qualifications, SBU applications, users, profiles and logout.
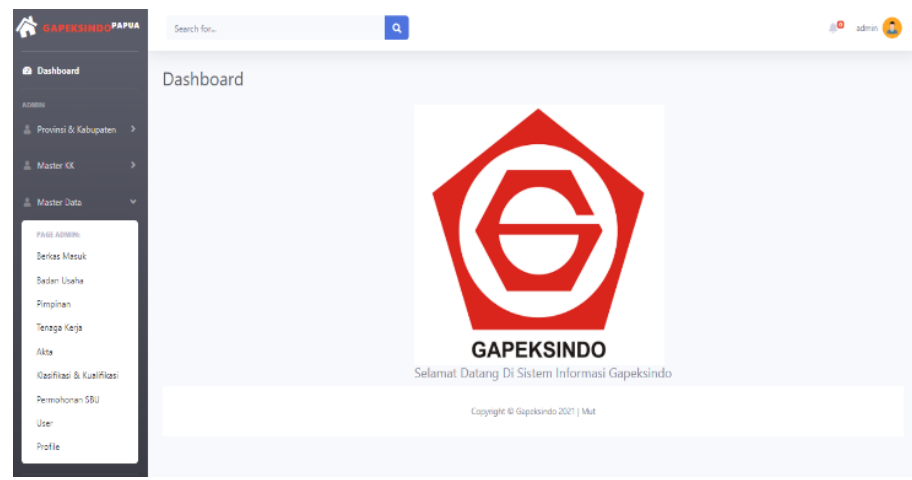

Figure 9 Main Menu Page Display 


\subsection{Business Entity Page Display}

On the business entity page, the admin can perform the process of adding, changing, deleting and looking for business entity data.

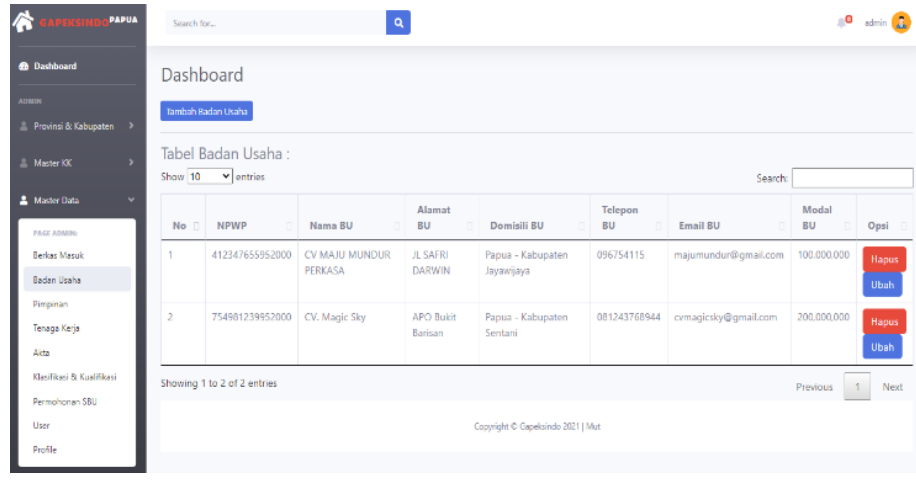

Figure 10 Bussiness Entity page Display

\subsection{SBU Application Page Display}

On the SBU application page, the VVA leader team can view detailed business entity data, print SBU application and SBU application report.
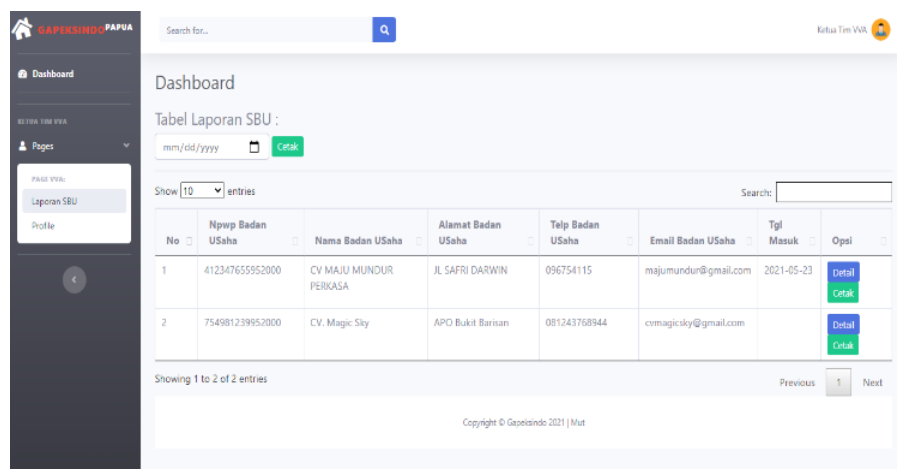

Figure 11 SBU Application Page Display

\subsection{SBU Application Details Page Display}

On the SBU application detail page, the VVA leader team can see the inputting details of business entity data. It consists of data on business entities, leaders, workers, certificates, and classifications \& qualifications.
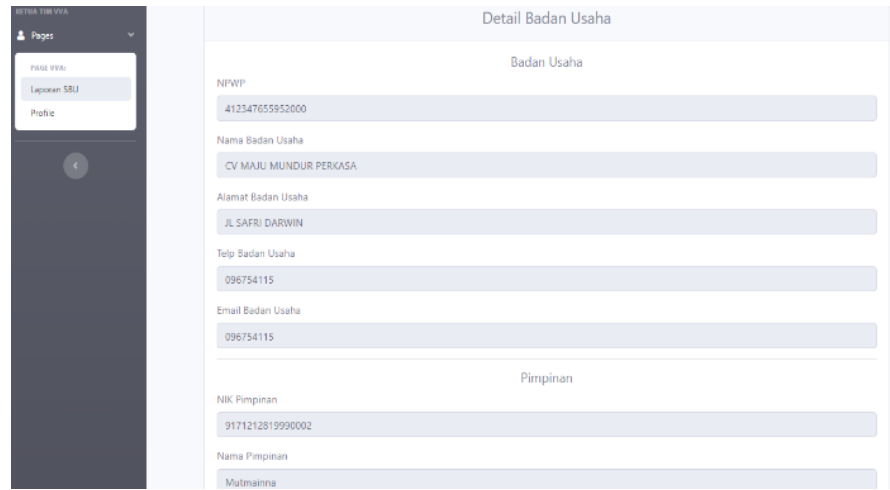

Figure 12 SBU Application Details Page Display 


\section{Conclusion}

Based on the results of the discussion about the Web-Based Information System of Construction Service on Papua Gapeksindo Association, it can be concluded that the Information System can help admins inputting and processing data more quickly, exactly and accurately. Thus, the admins can save time and energy than inputting it manually.

The Web-Based Information System of Construction Services on Papua Gapeksindo Association can function more optimally, there are several suggestions as follows:

1. It is necessary to develop the system to add document upload feature to each data form.

2. It is necessary to develop the system to make more attractive website page.

3. It is necessary to add notification feature for business entities to extend invalidate Business Entity Certificate.

\section{References}

[1] T. Abdurrachman and B. R. Suteja, "Pengembangan Sistem Informasi Asosiasi Jasa Konstruksi dengan Menerapkan Tanda Tangan Digital,” vol. 7, pp. 261-273, 2018.

[2] A. Simangunsong, "Sistem Informasi Pengarsipan Dokumen Berbasis Web," vol. 2, no. 1, pp. 11-19, 2018.

[3] D. Puastuti and K. S. Abb, "PERANCANGAN SISTEM INFORMASI PENDATAAN WARGA SEKOLAH BERBASIS WEB PADA SDN 2 PAGELARAN," vol. 3, no. 1, pp. 26-42, 2017.

[4] T. H. Ningrum, M. K. G. Umar, and . S., "Sistem Informasi Penerimaan Berkas Badan Usaha Jasa Konstruksi pada Lembaga Pengembangan Jasa Konstruksi (LPJK) Provinsi Maluku Utara," J. Ilm. Ilk. - Ilmu Komput. Inform., vol. 3, no. 1, pp. 43-51, 2020, doi: 10.47324/ilkominfo.v3i1.93.

[5] F. Yunita, “Analisa Dan Perancangan Sistem Informasi Izin Usaha Jasa Konstruksi,” J. Sist., vol. 6, no. September, pp. 52-59, 2017.

[6] A. Aliman, "Sistem Informasi Database Sertifikat Keterampilan Kerja (SKTK) pada LPJKD Aceh berbasis Web," J. JTIK (Jurnal Teknol. Inf. dan Komunikasi), vol. 4, no. 2, p. 75, 2020, doi: 10.35870/jtik.v4i2.118.

[7] C. Andari, D. R.-I. pdfa. Wijaya, and R. Budiawan, "Aplikasi Pendataan Kendaraan Hilang Berbasis Web ( Studi Kasus : Polres Cimahi )," vol. 1, no. 1, pp. 542-546, 2015.

[8] R. P. Ardhiyani and H. Mulyono, "INFORMASI PARIWISATA BERBASIS WEB SEBAGAI MEDIA PROMOSI PADA KABUPATEN TEBO," vol. 3, no. 1, pp. 952-972, 2018.

[9] F. S. Ariansyah; Fajriyah; Prasetyo, "RANCANG BANGUN SISTEM INFORMASI PENDATAAN ALUMNI PADA STIE PRABUMULIH BERBASIS WEBSITE DENGAN MENGGUNAKAN BOOTSTRAP,” vol. 17, no. 1, 2017. 